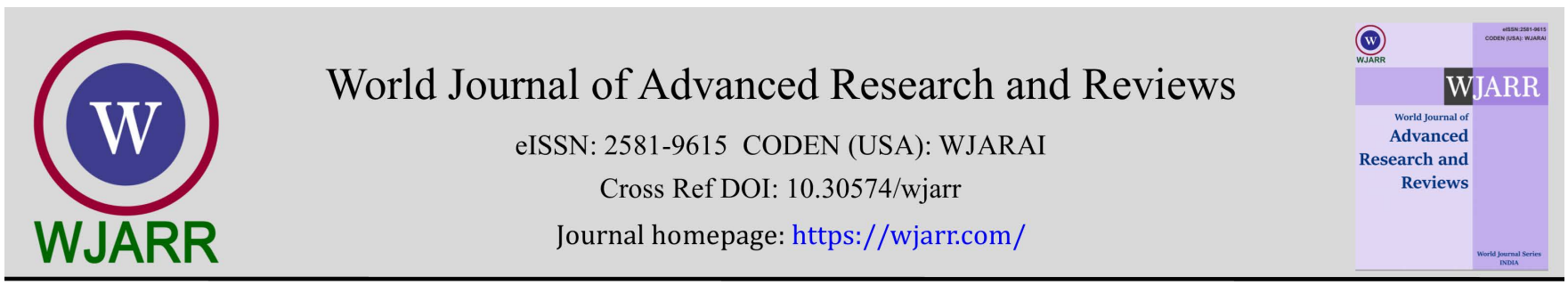

(REVIEW ARTICLE)

Check for updates

\title{
Phytoremediation: An innovative perspective for reclaiming contaminated environment using ornamental plants
}

\author{
Kirti Pandya *, Sanjukta Rajhans, Himanshu Pandya and Archana Mankad \\ Department of Botany, Bioinformatics and Climate Change Impacts Management, School of Science, Gujarat University, \\ Ahmedabad-380015, Gujarat, India.
}

World Journal of Advanced Research and Reviews, 2022, 13(02), 001-014

Publication history: Received on 21 December 2021; revised on 27 January 2022; accepted on 29 January 2022

Article DOI: https://doi.org/10.30574/wjarr.2022.13.2.0088

\begin{abstract}
The current state of our planet earth is not good and is deteriorating day by day. It is the after effect of centuries of ill treatment of earth and the natural resources. Due to continuous pollution by various natural as well as manmade activities, recovery of the earth is not possible. Amongst all, the heavy metal is the most salient category of contaminant found in our environment which seems very difficult to curb. Many steps and technologies have been developed by the researchers across the world to solve the problem of heavy metal contamination. Recognizing their toxicity, it has been found that heavy metals possess threat to the whole ecosystem. Thus, phytoremediation has emerged as the ecological and economic technique for withdrawing and removing heavy metals from the soil. This paper outlines the details of phytoremediation, the various processes involved in it, and about the potential ornamentals used for the remediation purpose.
\end{abstract}

Keywords: Non-hyperaccumulator; Ornamental Plants; Heavy metals; Phytoremediation; Accumulators; Excluders

\section{Introduction}

Natural resources are the naturally occurring materials that are very valuable to mankind. Among them, land and water are the two precious resources. They are the backbone of the human civilization and upon which the stability of whole agriculture depends. Miserably, they have been exposed to severe degradation and pollution in the recent years. The various anthropogenic activities are the major cause of misuse and mishandling of the resources leading to pollution of land, water, air and soil. Majority of environment and human health problems are due to contamination of these resources by organic and inorganic pollutants [1]. The source pollutants include effluents and solid waste discharge from the factories, excessive usage of pesticides, insecticides, fertilizers in agricultural fields, metals due to smelting and mining of mineral ore [2]. The only way to reduce the toxic effects of these pollutants is by their transformation from one form to another $[3,4]$. There are numerous ways which have been applied to purify the environment, but most of them are either costly or they are not preferrable at large scale. Some of the methods have side effects which make them inappropriate for the use in the long run.

Traditionally, remediation of the heavy metal contaminated soil involves either onsite management or excavation and subsequent dumping to a landfill site. The later method can be dangerous as it transfers the contaminants to a new location or site. Also handling of such pollutants can be risky. But recent concerns have solved the problem by developing relevant technologies that can be useful and economical. One of the approaches is the use of plants for the remediation purpose. This technique is known as "Phytoremediation". Phytoremediation is the use of plants for the removal of the contaminants from soil, water and sediments. The plant species with outstanding metal-accumulating

\footnotetext{
${ }^{*}$ Corresponding author: Kirti Pandya

Department of Botany, Bioinformatics and Climate Change Impacts Management, School of Science, Gujarat University, Ahmedabad380015, Gujarat, India.
}

Copyright (C) 2022 Author(s) retain the copyright of this article. This article is published under the terms of the Creative Commons Attribution Liscense 4.0. 
capacity are known as "Hyperaccumulator" plants [5]. Phytoremediation is a process for degrading harmful contaminants from the environment. Plant act as filters and also have the ability to remove the toxic elements from the soil and water [6]. It is an in-situ and eco-friendly technique that uses plants to remove toxic materials from the environment [7]. Phytoremediation has been derived from a Greek word Prefix- "Phyto" means Plant and Latin word "remedium" which means to recover or clean [8]. Being an innovative process, this method has provided an opportunity to owners of metal contaminated sites for getting a decontaminated area [9]. This technique is becoming more popular these days because people are becoming more aware about saving the environment [10].

\section{Worldwide environmental pollution}

According to Holgate MW [11] pollution is related to something that takes place at an inappropriate place, at unsuitable time and in an incorrect quantity. Different types of pollution include air, water, soil etc. each one of these have their own source for getting contaminated. According to Gudmundsson G. et al., [12] the sources of air pollution include burning of fossil fuels, leakage of volatile gases, vehicular traffic and industry produces. Prolonged exposure to these toxic gases can be dangerous to human health and can cause respiratory and cardiovascular problems. It can also cause deterioration of ecosystem an adversely affect agricultural and forestry productions, change in climatic conditions, corrosiveness of buildings and melting down of poles [13]. As stated by Nie, J. et al., [14] water pollution is caused by the release of waste water, chemical discharge from the factories, fertilizers, pesticides from the agricultural land and domestic sewage. The contamination of water leads to eutrophication, reduction in freshwater resources and ultimately leading to the pollution of aquatic ecosystem and waterborne diseases in humans [15]. Soil pollution is related to addition of toxic substances which changes the health of soil thus affecting the crop production and in the long run affecting the well-being of people [16]. Causes of soil pollution includes heavy metals, sewage and industrial waste from pesticides, fertilizers from the crop land [17]. Most important candidate for soil pollution are heavy metals. Various heavy metals are well known for causing toxic effects globally. Lots of cases related to heavy metal poisoning have been reported from different countries. Heavy metals are a group of heterogenous chemical element which are toxic in both the forms: elemental or soluble include Mercury, Zinc, Lead, Copper, Chromium, Cadmium, Nickel. Their existence in nature at very low concentration proves to be harmful and toxic.

\section{Origin of metal pollution}

Generally heavy metal contamination takes place due to various anthropogenic activities [18] which includes production of fuels, effluents from various types of industries including metal smelting, production of batteries, combustion of coal etc. [19]. Major source of pollution is caused by municipal waste disposal which is present in environment either in the form of landfills or sewage. Excessive use of chemicals in agriculture fields due to application of fertilizers and pesticides are also an important source of contamination by heavy metals [20].

\section{Heavy metal poisoning}

Heavy metals are unbreakable to simpler forms. These metals assemble inside the cellular compartments and hinder various enzymes functioning [21]. Heavy metals are not degraded biologically in soil. These can occur as free metal ions or its complexes due to anthropogenic activities. These activities lead to accumulation of various substances such as herbicides, radioactive elements and heavy metals.

\section{Heavy metals}

Heavy metals are defined as substances or elements possessing the metallic properties and with atomic number greater than 20, along with high density and atomic weight. The heavy metals do not degrade and remain present in the soil for long period of time [22]. Metals are naturally present in the soil. Depending on their function in biological system these metals are classified as essential and non-essential. The essential heavy metals are required by the plants for performing plant's biological and physiological processes during the entire life cycle [23]. They tend to be toxic when their concentration becomes high. Non-essential heavy metals do not have any important function, but also prove to be very toxic for the plants [24]. Some of the essential heavy metals includes Copper (Cu), Iron (Fe), Manganese (Mn), Nickel (Ni) and Zinc (Zn) which are required for plant growth and development. Some of the non- essential heavy metals includes Lead (Pb), Cadmium (Cd), Arsenic (As) and Mercury (Hg) which cause environmental pollution [25]. These heavy metals enter human body by the process of biomagnification and poses threat to health [26,27]. So, it is essential to block these heavy metals from entering the environment and thus reducing the contamination of land [28,29]. 


\subsection{Sources of heavy metals}

Table 1 represents the different sources of Heavy Metals.

Table 1 Different Sources of Heavy Metals

\begin{tabular}{|c|c|c|c|}
\hline $\begin{array}{c}\text { Serial } \\
\text { no. }\end{array}$ & $\begin{array}{l}\text { Heavy } \\
\text { metal }\end{array}$ & Sources & Reference \\
\hline 1 & Copper $(\mathrm{Cu})$ & $\begin{array}{l}\text { Heavy metals from electroplating industry, mining smelting and refining } \\
\text { process. }\end{array}$ & [30] \\
\hline 2 & $\begin{array}{l}\text { Mercury } \\
(\mathrm{Hg})\end{array}$ & $\begin{array}{l}\text { Metal released due to volcanic eruption, forest fire, burning of wood, } \\
\text { emissions from the industries releasing caustic soda, coal and peat. }\end{array}$ & [31] \\
\hline 3 & Zinc (Zn) & $\begin{array}{l}\text { Releases from the electroplating industries, smelting, mining and refining } \\
\text { procedure. }\end{array}$ & [30] \\
\hline 4 & Lead $(\mathrm{Pb})$ & $\begin{array}{l}\text { Lead releases from mining and smelting of metallic ores, municipal and } \\
\text { industrial sewage waste containing Lead (Pb), burning of Gasoline enriched } \\
\text { in lead. }\end{array}$ & {$[4,32]$} \\
\hline 5 & Nickel (Ni) & $\begin{array}{l}\text { Nickel releases from the Gaseous exchange occurring in the ocean, } \\
\text { weathering of geological matter and soil and forest fires. }\end{array}$ & [33] \\
\hline 6 & $\begin{array}{l}\text { Selenium } \\
\text { (Se) }\end{array}$ & $\begin{array}{l}\text { Combustion of fossil fuels. Selenium release from glass industry, refining of } \\
\text { oil, synthesis of varnish and pigments. }\end{array}$ & [34] \\
\hline 7 & $\begin{array}{l}\text { Chromium } \\
\text { (Cr) }\end{array}$ & $\begin{array}{l}\text { Solid waste release from tanneries, sludge waste and electroplating } \\
\text { industry. }\end{array}$ & [33] \\
\hline 8 & $\begin{array}{l}\text { Cadmium } \\
\text { (Cd) }\end{array}$ & $\begin{array}{l}\text { Sewage sludge, burning of fossil fuels, fertilizers, refining and smelting of } \\
\text { metals. anthropogenic activities and geogenic sources. }\end{array}$ & {$[35,36,37]$} \\
\hline 9 & Arsenic (As) & $\begin{array}{l}\text { The sources of arsenic include semiconductors, volcanoes, coal power and } \\
\text { plant preservatives. }\end{array}$ & {$[38,39]$} \\
\hline
\end{tabular}

\section{Consequences of heavy metals on plants}

The heavy metals are present in soluble form in the soil [40]. These heavy metals include essential as well as nonessential metals. Although, plants require the essential metals which are required for the growth of plants but increase in the concentration of these heavy metals can lead to toxicity. Along with the essential metals the non-essential metals also get concentrate in the plants [41]. It is known that these cannot be reduced to simpler forms instead they get accumulated inside the plant and prove to be detrimental. As the concentration of these metals increase, they constraint the various enzymes and causes stress conditions. Due to rise in the concentration of heavy metals in the soil, decrease in the growth of plant and beneficial soil microbes takes place [42]. One of the major drawbacks is that it reduces the amount of organic matter in the soil and enables the soil to lose fertility. Further the plants receive low mineral nutrition, hinderance in the photosynthesis process along with reduction in the activity of enzymes.

\section{Techniques for reclaiming the contaminated soil}

The removal of heavy metals from the soil is a strenuous job, explicitly for the large scale. Soil contains inorganic, organic, water and mixture of various gases in different quantities. The mineral constituents also differ depending on the parent rock from which the particular soil has formed under specific climatic conditions. Soil differs in chemical, physical and biological characteristics. The movement of soil water is affected by texture and soil structure. Other properties of soil include mobility of solute, solubility of the salt, various chemical and microbial activities and finally the bio-assimilation of metals. Therefore, the best technique which takes heed of all the properties of soil is "Phytoremediation". Variety of approaches for reclaiming the polluted soil includes the following-

Physiochemical process - It includes excavating, entombing it to the dump site, obstructing and percolation of metals from the soil and purifying [43] followed by ion-exchange and microfiltration [44]. This method has side effects and is costly at the same time $[2,45]$. 
Biological approaches- include two methods-

- Using microbes for detoxifying the metals by extracellular chemical precipitation, transformation and volatilization. Some micro-organisms also have the ability to reduce the metals by their metabolic processes [34].

- Using certain plants for absorbing and transferring the metals to above ground parts via roots is known as phytoremediation. This process is quite cheaper compared to physiochemical approach $[2,3,45]$. This technique can be applied for organic as well as inorganic pollutants found in the soil, water or air [43]. Though uptake of heavy metals varies greatly from species to cultivars [34].

\subsection{Working process of phytoremediation}

According to Vasavi, A. et al., [9] the working process of phytoremediation includes recognition of region, chemical examination of the soil sample of the region, growing of hyperaccumulator species, utilization of standard system and survey of vegetation, collection and dehydration of plants, chemical examination of soil after phytoremediation, diagnosis of leaves and estimating the concentration factors.

The various qualities which one should keep in mind before selecting the plants for phytoremediation are -

- High growth

- The plant should be able to concentrate more quantities of heavy metals in its above ground parts.

- The plant should be tolerant towards the toxins.

\subsection{Procedure of heavy metal uptake}

Many researchers have examined the mechanism of heavy metal uptake. Sinha, R. K. et al., [46] states that plants can behave as 'accumulator' and 'excluders' both. The difference between both is that excluders limit the uptake of heavy metals into biomass but the accumulators as the name itself suggests sustain and survive while accumulating metals inside the plant tissues.

Plants have emerged with outstanding methods to derive crucial micronutrients from the surrounding, even at low concentration levels. Plant roots, assisted by redox reactions, various $\mathrm{pH}$ changes and chelating agents produced by the plants, help in solubilizing and absorbing the micronutrients from very low and insoluble precipitates as well. Hence, the absorption of micronutrients plays significant role in phytoremediation. The absorption and translocation of heavy metals in plant involves peculiar type of protein pumps which are generally found embedded in the cell membrane of plants that utilize energy to form electrochemical gradient. The other pump includes co and anti-transporters, these protein pump uses the electrochemical gradients produced by ATPases which helps in transporting ions to the cells. Likewise different ions are up taken from root and transported to shoot along with heavy metals by using the two pumps. These uptake mechanisms of plants are regulated very closely. The needs of the plant ranges from 10-20 concentration levels of trace elements required for the purpose. The only exceptions are the hyperaccumulator species [47] Evapotranspiration helps in the evaporation of water from leaves of plants, they act as pumps to absorb nutrients and soil materials into the roots of the plant. As the contaminants are transported from roots to above ground parts which are harvested at later stage. At the same time the soil conditions remain uninterrupted. The hyper-accumulators have exceptional ability of keeping the ratio of shoot to that of root as 1, unlike the non-hyperaccumulator plant species in which the ratio is less than 1 .

\section{Elements influencing the uptake operation}

Many factors are responsible for the uptake procedure of heavy metals. Awareness about all these factors is very essential for the improved performance of the plants.

- $\quad$ Plant species- it is one of the first and foremost step to select and screen the plant species which has high caliber of remediation [48]. The uptake of any element solely depends on the characteristics of the plant [49].

- Quality of the media/ medium- A variety of agronomic practices such as addition of the chelators or modifications in $\mathrm{pH}$ range, magnify the process of remediation.

- $\quad$ Rhizosphere/Root zone- The principal area or zone of absorption. The contaminants are stored or metabolized inside the tissues of the plant.

- Uptake by vegetative means-various conditions influenced by the environment like temperature affects the growth parameters. For example, the root length is affected by temperature. 
- $\quad$ Solubility of metal- Metal take up by the plants depend on the solubility and bioavailability of the particular metal in water medium. Other factors on which it depends include retention and interaction of metal with other substances in water. If the heavy metal is bound to soil than it will depend on the various other factors including redox reaction, $\mathrm{pH}$, contents of organic matter present in the soil.

- $\quad$ Addition of chelating agents- The uptake of heavy metals can be accelerated by the addition of chelating agents which increases the rate of remediation and further the duration and cost is also reduced [50].

\section{Role of ornamental plants in phytoremediation}

For successful phytoremediation the selection of plants plays an important role. The plants should be selected in such a way that they are tolerant towards the particular metal and adapt itself in the same area. The plant should also be effective in proper remediation and should furnish economic benefits along with the remediation of the environment.

\subsection{Usage of ornamental plants for phytoremediation purpose}

Ornamental plants are the plants which are cultivated for the purpose of decoration, increasing the aesthetics of an area. There are wide range of ornamental plants which comprises of various shapes, sizes, colour, adaptation to climate and landscape. Different types of ornamental plants are grown as per the need of gardening. Some plants are cultivated for their flowers while others are cultivated for their leaves, fragrance, fruit and stem. The ornamental plants include various classes of plants like-

- $\quad$ Terrestrial - Aquatic plants

- Herbaceous - Woody plants

- Higher - Lower plants

The terrestrial plants are further subdivided depending upon the ornamentations comprising of either flower or foliage. Likewise aquatic plants are classified on the basis of position of the roots and leaves like-

- $\quad$ Floating

- Emergent

- $\quad$ Submergent

Some examples of ornamental plants which are used for phytoremediation are Calendula officinalis, Tagetes erecta, Tagetes patula, Euphorbia milii, Melastoma malabathricum, Celosia cristata pyramidalis, Helianthus annus. Some aquatic ornamental plants include Iris sp., Zantedeschia aethiopica, Nelumbo nucifera, Nymphaea etc.

\subsection{Characteristics of various parts of ornamental plants}

Due to presence of wide range of ornamentals, it is impractical and time consuming to evaluate each and every ornamental plant one after other. So, the potential plants with high phytoremediation are evaluated based on their morphology. Root density and surface area play an important role in the uptake of contaminants from the soil. The characteristics of leaf like leaf area index also play crucial role in volatilization and excretion. The most important advantage of using ornamental plants for phytoremediation is that it does not affect any of the living forms by entering into the food chain. As ornamental plants are non-edible and are used only for decoration purpose. The heavy metal accumulation depends majorly on the type of metals, its bioavailability, geological and environmental factors [48] Table 2 represents the various ornamental plants and metal up taken by them.

Table 2 Ornamental plants for phytoremediation

\begin{tabular}{|c|c|c|c|c|c|}
\hline Sr. No & Botanical Name & Metals & Treatment & Results & Reference \\
\hline 1 & $\begin{array}{l}\text { Iris lactea and Iris } \\
\text { tectorum }\end{array}$ & Cadmium & $\begin{array}{l}\text { System- hydroponic } \\
\text { Treatment- Hoagland } \\
\text { solution along with } \\
\mathrm{CdCl}_{2}\left(2-50 \mathrm{mg}^{\left.-\mathrm{cdl}^{-1}\right)}\right.\end{array}$ & $\begin{array}{l}\text { Cadmium } \\
\text { accumulated in both } \\
\text { the species of Iris. } \\
\text { Accumulation was } \\
\text { found higher in roots } \\
\text { than shoot. }\end{array}$ & [51] \\
\hline
\end{tabular}




\begin{tabular}{|c|c|c|c|c|c|}
\hline 2 & Iris pseudacorus & $\begin{array}{l}\text { Chromium } \\
\text { and Zinc }\end{array}$ & $\begin{array}{l}\text { System- hydroponic } \\
\text { Treatment- peat and } \\
\text { perlite (50/50) in } \\
\text { addition to } \mathrm{ZnCl}_{2} \\
(0.07-1.5 \mathrm{Mm} \text { and } \\
\mathrm{CrCl}_{3}(0.04-0.8 \mathrm{mM} \quad \mathrm{Cr} \\
\text { (III) }\end{array}$ & $\begin{array}{l}\text { Iris showed the } \\
\begin{array}{l}\text { capability } \\
\text { accumulation of } \mathrm{Cr} \\
\text { and Zn. }\end{array}\end{array}$ & [52] \\
\hline 3 & $\begin{array}{l}\text { Nymphaea } \\
\text { spontanea }\end{array}$ & Chromium & $\begin{array}{l}\text { System- hydroponics } \\
\text { Treatment- } \\
\mathrm{K}_{2} \mathrm{Cr}_{2} \mathrm{O}_{7}\left(1-10 \mathrm{mg} \mathrm{l} \mathrm{l}^{-1}\right) \text {, } \\
\text { binary metals } \mathrm{Cr}(\mathrm{VI}) \\
2.5 \mathrm{mg} \mathrm{l}^{-1} \text { and } \mathrm{Cu}\left(\mathrm{NO}_{3}\right)_{2} \\
\left(\mathrm{Cu}(\mathrm{II}) 0.5 \mathrm{mg} \mathrm{l}^{-1}\right)\end{array}$ & $\begin{array}{l}\text { The accumulation of } \\
\mathrm{Cr}(\mathrm{VI}) \text { in water lilies } \\
\text { is absorbed highest in } \\
\text { roots, leaves, petioles. } \\
\text { At maturity the } \\
\text { removal of metal is } \\
\text { higher. }\end{array}$ & [5] \\
\hline 4 & $\begin{array}{l}\text { Zantedeschia } \\
\text { aethiopica }\end{array}$ & Iron & $\begin{array}{l}\text { System- Hydroponic } \\
\text { Treatment- Nutrient } \\
\text { solution with addition } \\
\mathrm{FeSO}_{4}\left(100 / 200 \mathrm{mg} \mathrm{l} \mathrm{l}^{-}\right. \\
\left.{ }^{1}\right)\end{array}$ & $\begin{array}{l}\text { This plant is } \\
\text { moderately tolerant } \\
\text { to high concentration } \\
\text { of iron. }\end{array}$ & [53] \\
\hline 5 & Nerium oleander & Lead & $\begin{array}{l}\text { System- hydroponic } \\
\text { Treatment- Nutrient } \\
\text { solution added with Pb } \\
\left(\mathrm{NO}_{3}\right)_{2}(20-100 \mathrm{~m} \mathrm{~Pb})\end{array}$ & $\begin{array}{l}\text { The accumulation of } \\
\text { lead in plants reduced } \\
\text { the growth of plant } \\
\text { and accumulated } \\
\text { malondialdehyde in } \\
\text { the leaves. }\end{array}$ & [54] \\
\hline 6 & $\begin{array}{l}\text { Helianthus annus, } \\
\text { Taegetes patula, } \\
\text { Celocia cristata }\end{array}$ & $\begin{array}{l}\text { Calcium, } \\
\text { Chromium, } \\
\text { Iron, } \\
\text { Copper, } \\
\text { Zinc, Lead }\end{array}$ & $\begin{array}{l}\text { System- Pot } \\
\text { Treatment- } \\
\text { Contaminated soil }\end{array}$ & $\begin{array}{l}\text { All of them had good } \\
\text { accumulation } \\
\text { capability. It was } \\
\text { highest in root } \\
\text { followed by leaves, } \\
\text { stem and flower. }\end{array}$ & [55] \\
\hline 7 & $\begin{array}{l}\text { Calendula } \\
\text { officinalis }\end{array}$ & Cadmium & $\begin{array}{l}\text { System-pot } \\
\text { Treatment- EDTA, } \\
\text { EGTA }\end{array}$ & $\begin{array}{l}\text { Application of EDTA } \\
\text { lead to reduced } \\
\text { growth. } \\
\text { increased EGTA } \\
\text { accumulation of Cd }\end{array}$ & [56] \\
\hline 8 & Calendula alata & $\begin{array}{l}\text { Cesium, } \\
\text { lead }\end{array}$ & $\begin{array}{l}\text { System- hydroponics } \\
\text { Treatment- Nutrient } \\
\text { solution added with } \\
\mathrm{CsCl}(0.6-5 \mathrm{mg} \mathrm{CsCl-1}) \\
\text { or } \mathrm{Pb}\left(\mathrm{C}_{2} \mathrm{H}_{3} \mathrm{O}_{2}\right)_{2} \quad(0.6- \\
\left.5 \mathrm{mg} \mathrm{Pb} \mathrm{l}^{-1}\right)\end{array}$ & $\begin{array}{l}\text { Calendula showed } \\
\text { very fast growth and } \\
\text { was able to remediate } \\
\mathrm{Cs} \text { and } \mathrm{Pb} \text {. }\end{array}$ & [57] \\
\hline 9 & Helianthus annus & $\begin{array}{l}\text { Cadmium, } \\
\text { Zinc }\end{array}$ & $\begin{array}{l}\text { System-pot } \\
\text { Treatment- } \\
\text { amendments stress- } \\
\mathrm{Cd} \quad \text { and } \\
\text { contaminated soil. }\end{array}$ & $\begin{array}{l}\text { Amendment } \mathrm{KCl} \\
\text { increased Zn and } \mathrm{Cd} \\
\text { accumulation }\end{array}$ & [58] \\
\hline 10 & Helianthus annus & Mercury & $\begin{array}{l}\text { System-pot } \\
\text { Treatment-Cytokinin } \\
\text { and ammonium } \\
\text { thiosulfate }\end{array}$ & $\begin{array}{l}\text { Addition of Cytokinin } \\
\text { and ammonium } \\
\text { thiosulfate increased } \\
\text { the absorption and } \\
\text { translocation } \\
\text { mercury. }\end{array}$ & [59] \\
\hline
\end{tabular}


World Journal of Advanced Research and Reviews, 2022, 13(02), 001-014

\subsection{Techniques of phytoremediation}

Phytoremediation takes place through one or more techniques like Phytostabilization, phytoextraction, phytovolatilization and rhizofiltration.

\subsubsection{Phytostabilization}

Phytostabilization is a technique in which plants immobilize the contaminants in the soil or ground water. The heavy metals are disabled underground. This process helps to decrease the bioavailability and prevent the risk of heavy metal from entering in the food chain $[60,61]$.

\section{Phytostabilization combines different processes-}

- Decrease in metal valence in the root.

- Imbibition and sequestration in the root tissues and cell walls [62,28].

The growth of plants helps in preserving the soil health of contaminated area [63]. The plant species grown for remediation at the particular site not only helps to stop the leaching of chemicals into the ground water but also prevents the dispersal of contaminated soil by wind $[64,65]$. This process of phytoremediation involves on spot-deactivation. Generally, the remediation of sludges, sediments, soil takes place by this method [66]. Immobilization of various contaminants in the soil is done by roots through the process of accumulation and absorption. This method has many advantages like lowering the movement of various contaminants, stopping the displacement and pollution of ground water, assimilability into food chain and helping in the restoration of flora. Various plant species which are tolerant to heavy metals are selected for this purpose. This technique is very useful for treating metals such as Chromium (Cr), Zinc $(\mathrm{Zn})$, Arsenic (As), Lead (Pb), Cadmium (Cd), Copper (Cu). Phytostabilization is very useful for discarding harmful and dangerous wastes while keeping the ground water maintained. The efficiency of phytostabilization can be increased by addition of organic and inorganic amendments. Incorporation of amendments has a variety of benefits including increase in necessary nutrients in the soil and organic matter. The application of these soil amendments also alters the $\mathrm{pH}$ value, redox condition of soil, speciation of metals etc. $[67,68,69]$. This also helps in increasing the water holding capacity of the soil and colonizing of plant species. The microbes like bacteria, which inhabit roots can help in immobilizing the metals. They absorb contaminants into their cell walls. The processes such as generating chelators and advancement in the process of precipitation can be helpful in future [70,71,72]. According to Gohre, V, Paszkowski, U. [70] the mycorrhiza and bacteria present in the rhizosphere also help to increase the root surface and depth to ease the process of phytostabilization.

\subsubsection{Phytoextraction/Phytoaccumulation}

The process of phytoextraction implies the uptake of contaminants from the soil or water by the roots. The contaminants are translocated and accumulated in the various above ground parts such as leaves and stems of the plants [73,74]. This technique is mainly applied to treat the polluted soil. It has been demonstrated by Salt, D.E. et al., [73] that the cost of phytoextraction would be ten times less than that of traditional methods. During current times, the most crucial technique among phytoremediation is phytoextraction [75,76]. Phytoextraction is a persistent and long-lasting technique and can be used on commercial scale.

Step wise procedure of phytoextraction includes mobilizing the heavy metals in roots, translocating heavy metals from roots to aerial parts and sequestering it to tissues [75]. This process is very effective in remediating metals like Copper $(\mathrm{Cu})$, Nickel (Ni), Zinc (Zn). The major advantage of this technology is the reduction of waste or pollutant up to $95 \%$ [66].

The performance of phytoextraction depends on selection of plant, performance of plant, bioavailability of heavy metal, soil and properties of roots [63]. Proper selection of plant is important for efficient phytoextraction.

The plants selected should have the following qualities- Considerable root system, extremely tolerant to heavy metals, high extraction capability, more resistance towards microbes and pests' adaptability to present environment, capability to grow in unhealthy soil conditions, ease in cultivation and harvest $[75,77]$

Among, the qualities, above ground parts and metal accumulating abilities are the two important characters which are responsible in determination of phytoextraction capabilities. There are two strategies for selection of plant species 1) use of hyperaccumulator plant and 2) high above ground biomass [75,78,79]. For successful phytoextraction a good 
hyperaccumulator plant species is selected which can concentrate more amount of metal that is 500 times more than a typical species. A plant is said to be hyperaccumulator species when it fulfils criterion described below-

- The concentration ratio of root to shoot should be higher than 1.

- $\quad$ For metals such as $\mathrm{Ai}, \mathrm{As}, \mathrm{Co}, \mathrm{Cr}, \mathrm{Ni}$ and Se the concentration ratio should be greater than $0.1 \%$.

For Cadmium (Cd) it should be higher than $0.01 \%$ and that for Zinc it should be higher than $1.0 \%$. Hyperaccumulator plant have capacity to accumulate increased levels of metals without showing any symptoms of phytotoxicity [80,81]. Finding a practical hyperaccumulator is the simple blueprint for phytoremediation to be successful. Presently, nearly 45 angiosperm families ranging from herbs, shrubs to trees with more than 450 species of plants which are hyperaccumulator have been identified [82].

Table 3 Plant species with particular metal accumulation capacity

\begin{tabular}{|c|l|c|}
\hline Metal & Hyperaccumulator Plant species & References \\
\hline $\mathrm{Se}$ & Lecythis ollaria & {$[61]$} \\
\hline $\mathrm{Zn}$ & Thlaspi caerulescens & {$[8]$} \\
\hline $\mathrm{Pb}$ & Minuartia verna & {$[83]$} \\
\hline $\mathrm{Pb}$ & Agrostis tenuis & {$[83]$} \\
\hline $\mathrm{Co}$ & Haumaniastrum robertii & {$[61]$} \\
\hline $\mathrm{Cu}$ & Aeollanthus subacaulis & {$[83]$} \\
\hline $\mathrm{Zn}$ & Dichapetalum gelonioides & {$[83]$} \\
\hline $\mathrm{Zn}$ & Thlaspi tatrense & {$[83]$} \\
\hline $\mathrm{Mn}$ & Maytenus bureaviana & {$[61]$} \\
\hline $\mathrm{Ni}$ & Psycotria vanhermanni & {$[83]$} \\
\hline $\mathrm{Ni}$ & Streptanthus polygaloides & {$[83]$} \\
\hline $\mathrm{As}$ & Pteris vittata & {$[84]$} \\
\hline $\mathrm{Zn}, \mathrm{Cd}$ & Sedum alfredii & {$[83]$} \\
\hline $\mathrm{Cd}, \mathrm{Pb}$ & Taegetes erecta & {$[85,86]$} \\
\hline $\mathrm{Cd}, \mathrm{Pb}$ & Coleus blumei & {$[87]$} \\
\hline $\mathrm{Pb}, \mathrm{Cd}$ & Datura stramonium L. & \\
\hline $\mathrm{Cd}, \mathrm{Pb}$ & Impatiens balsamia & {$[80]$} \\
\hline
\end{tabular}

The most important or key point which one should keep in mind during selecting a hyperaccumulator plant is that edible crops must be avoided for the purpose of phytoremediation. It can enter food chain and become toxic to humans and animals. One must select non-edible hyperaccumulator plants for the effective phytoremediation.

Hyperaccumulation helps in eliminating the metals from the plants by the process of compartmentalization of these heavy metals in the large compartments of the vacuole or other parts of the plant cell such as cell wall and thereby they do not disturb the vital activities or processes like cellular division and respiration. For increasing the performance of the process of phytoextraction the selected plant should have higher biomass as well as growth rate which can result in proper remediation. Another approach of phytoextraction includes the addition of chelates or chelating agents. The most important advantage of using a chelating substance is that it helps in the formation of metal chelate complexes. This complex is easily absorbed by the plants. Thus, can be available to shoot; thereby making the bioavailability of metals in the soil [61]. Some of the examples of chelates are as follows. 
Table 4 Different Chelating Agents for Phytoextraction

\begin{tabular}{|l|l|}
\hline EDTA & Ethylenediaminetetraacetic acid \\
\hline CDTA & Trans-1,2-diaminocyclohexane-N, N, N', N'-tetra acetic acid \\
\hline EDDS & SS-ehtylenediamine disuccinic acid \\
\hline EDDHA & Ethylenediamine-di-o-hydoxyphenylacetic acid \\
\hline HEDTA & N-hydroxyethylenediaminetriacetic acid \\
\hline DTPA & diaethylenetriaminepentaacetic acid \\
\hline
\end{tabular}

Other chelates include malic acid and citric acid which are organic in nature and can help in the phytoextraction. EDTA mentioned above in the table 4 is synthetic in nature which is used extensively over any other synthetic chelates. As it enhances the meal uptake by plants and is a cheaper synthetic substitute [91]. The major disadvantage of using a chelate is that it can pollute the ground water. It is harmful for plants and micro-organisms present in the soil [92].

\subsubsection{Phytovolatilization}

This technique involves the plants to draw the toxic metals from soil which modifies them into volatile forms and thereby transpiring into the atmosphere [66]. As the process involves volatilization of the contaminants it is transpired from the surface of the leaves. The method gains advantage in remediating soil containing Mercury ion. The toxic form of mercuric ion (Hg) is converted to elemental mercury (Hg) which is less toxic [42]. This transformed mercury will further get deposited again in the water bodies such as lakes and river following precipitation. Successively increasing the growth of anaerobic bacteria and contributes towards the production of methyl-mercury in the process. The Selenium (Se) polluted soil can be remediated by this method. This process can also be applied to convert the inorganic selenium into organic form of selenium which includes selenocysteine. Brassica juncea and Brassica napus are the plant species which have been used to treat selenium polluted soil. The major advantage of using this method is that contaminants are converted to gas or volatile form which does not require any harvest or disposal. One drawback is that the contaminant is not fully removed instead it gets transferred from soil to air [64].

\subsubsection{Rhizofiltration}

It can also be termed as 'Phytofiltration' and includes other forms such as -

- $\quad$ Rhizofiltration - which uses the plant roots for filtration of contaminants.

- Blastofiltration - use of seedlings to remove the contaminants from the waste water [93].

- Caulofiltration - which uses the shoots of the plant for filtration of contaminants.

During the process of rhizofiltration the heavy metals are either adsorbed or absorbed by the roots of the plant. Rhizofiltration is used in remediating the wastewater which contains less contaminants. Heavy metals including Lead, Chromium, Zinc, Copper, Cadmium are precipitated by the roots [66]. The plants selected for rhizofiltration should have dense root system, higher biomass produce and should be tolerant to heavy metals [63]. Terrestrial as well as aquatic plants are suitable for rhizofiltration.

\section{Benefits and Limitations of phytoremediation}

The technology of phytoremediation has various benefits in contrast to physiochemical methods. Various benefits and limitations are described below $[94,95]$.

Benefits- Phytoremediation is an eye soothing, aesthetical and eco-friendly technique which mainly emphasizes on the use of plants. The technology can be used in-situ and ex-situ. It is very useful for wide spectrum of contaminants. The process of phytoremediation is cost effective as compared to other methods such as traditional processes. This method also conserves the natural form of the environment. Supervision and observation of plants is also easier. The probability of restoration as well as recycling of metals is possible. There is minimal disturbance to the environment.

Limitations- The process of phytoremediation is beneficial for the site which has the depth of less than 5 meters [1]. It is a time-consuming process. The growth of plants may be affected depending on the climatic changes. The rate of 
survival of plants is directly related to the toxicity of the various contaminants present. There is a great risk of entering into the food chain which eventually affects the ecosystem as a whole.

\section{Conclusion}

Heavy metal pollution is an important issue because of toxic effects and fast accumulation in the environment. To mitigate the pollution of heavy metal, a range of technologies and methods have been developed. Among all, phytoremediation is an emerging tool for creating revegetation of the contaminated soil with public acceptance and various advantages compared to other approaches. This paper highlights the various techniques, steps and factors affecting uptake of the heavy metals. The paper has also emphasized on the use of hyperaccumulator species for increasing the uptake of heavy metals up to many folds. Furthermore, the paper highlights the various sources of heavy metal pollution and its consequences. Most importantly the review has focused on the use of ornamental plants for remediation purpose. Among all the most important factor is the selection of suitable plant species along with other factors which are mentioned in this paper. Though, Phytoremediation is the best alternative it also consists of some drawbacks. More continued and prolonged research needs to be done to reduce the limitations in order to apply it effectively.

\section{Compliance with ethical standards}

\section{Acknowledgments}

My special thanks to Professor Dr. Himanshu Pandya, Professor Dr. Archana Mankad and Ms. Sanjukta Rajhans for their guidance and support.

\section{Disclosure of conflict of interest}

Hereby, all the authors declare no conflict of interest.

\section{References}

[1] Lee JH. An overview of phytoremediation as a potentially promising technology for environmental pollution control. Biotechnology and Bioprocess Engineering. 2013; 8(3): 431-439.

[2] McGrath SP, Zhao FJ, Lombi E. Plant and rhizosphere process involved in phytoremediation of metalcontaminated soils. Plant. Soil. 2001; 232(1/2): 207-214.

[3] Garbisu C, Alkorta I, Phytoextraction: A cost effective plant- based technology for the remove of metals from the environment. Bioresource Technology. 2001; 77(3): 229-236.

[4] Gisbert C, Ros R, De Haro A, Walker Dj, Pilar Bernal M, Serrano R, Navarro-Avino J. A plant genetically modified that accumulates $\mathrm{Pb}$ is especially promising for phytoremediation. Biochemical and Biophysical Research Communications. 2003; 303(2): 440-445.

[5] Choo TP, Lee CK, Low KS, Hishamuddin O. Accumulation of Chromium (VI) from aqueous solutions using Water lilies (Nymphaea spontanea). Chemosphere. 2006; 62(6): 961-967.

[6] Sumira J, Javid AP. Approaches to heavy metal tolerance in plants. 1st ed. Singapore: Springer Nature. 2016.

[7] Wu Z, Ba nuelos GS, Lin ZQ, Liu Y, Yuan L, Yin X, Li M. Biofortification and phytoremediation of selenium in China. Frontiers in Plant Sciences. 2015; 6(1): 136.

[8] Cunningham SC, Berti WR. Phytoextraction and Phytostabilization: Technical, Economic, and Regulatory Considerations of the Soil-Lead Issue. In: Terry, N. and Banuelos, Phytoremediation of Contaminated soil and water. 1st ed. USA: Lewis Publishers. 2000; 359-376.

[9] Vasavi A, Usha R, Swamy PM. Phytoremediation - an overview Review. Journal of Industrial Pollution Control. $2010 ; 26(1): 83-88$.

[10] Liu J, Xin X, Zhou Q. Phytoremediation of contaminated soils using ornamental plants. Environmental Science and pollution Research. 2018; 26(1): 43-54.

[11] Holgate MW. A perspective of environmental pollution. UK: Cambridge University Press. 1980. 
[12] Gudmundsson G, Finnbjornsdottir RG, Johannsson T, Rafnsson V. Air pollution in Iceland and the effects on human health. Review. Laeknabladid. 2019; 105(10): 443-452.

[13] Matyssek R, Clarke N, Cudling P, Mikkelsen TN, Tuovinen JP, Wieser G, Paoletti E. Climate change, Air pollution and Global challenges. Climate Change, Air pollution and Global Challenges- Understanding and perspectives from Forest Research. 1st ed. Netherlands: Elsevier. 2013.

[14] Nie J, Feng H, Witherell BB, Alebus M, Mahajan MD, Zhang WG, Yu LZ Causes, Assessment, and treatment of nutrient (N and P) Pollution in rivers, Estuaries, and Coastal Waters. Current Pollution Reports. 2018; 4(2): 154161.

[15] Xu CD, Xing DF, Wang JF, Xiao GX. The lag effect of water pollution on the mortality rate for esophageal cancer in a rapidly industrialized region in China. Environmental Science and pollution research. 2019; 26(32): 3285232858.

[16] Golui D, Datta SP, Dwivedi BS, Meena MC, Varghese E, Sanyal SK, Ray P, Shukla AK, Trivedi VK. Assessing soil degradation in relation to metal pollution-A Multivariate Approach. Soil and sediment contamination. 2019; 28(7): 630-649.

[17] Chen B, Stein AF, Castell N, Gonzalez-Castanedo Y, De La Campa AS, De La Rosa J. Modelling and evaluation of urban pollution events of atmospheric heavy metals from a large $\mathrm{Cu}$ - Smelter. Science of the Total Environment. 2016; 539(1): 17-25.

[18] Dembitsky V. Natural occurrence of arseno compounds in plants, lichens, fungi, algal species, and microorganisms. Plant Science. 2003; 165(6): 1177-1192.

[19] Zhen-Guo S, Xian-Dong L, Chun-Chun W, Huai-Man Ch, Hong ch. Lead Phytoextraction from contaminated soil with soil with high biomass plant species. Journal of Environmental Quality. 2002; 31(6): 1893-1900.

[20] Jadia CD, Fulekar MH. Phytotoxicity and remediation of heavy metals by fibrous root grass (Sorghum). Journal of Applied Biosciences. 2008; 10(1): 491-499.

[21] Jadia CD, Fulekar MH. Phytoremediation of heavy metals: Recent techniques. African Journal of biotechnology. 2009; 8(6): 921-928.

[22] Suman J, Uhlik 0, Viktorova J, Macek T. Phytoextraction of heavy metals: a promising tool for clean-up of polluted environment? Frontiers in Plant Science. 2018; 9(1): 1476.

[23] Cempel M, Nickel G. Nickel: a review of its sources and environmental toxicology. Polish Journal of Environmental Studies. 2006; 15(3): 375-382.

[24] Fasani E, Manara A, Martini F, Furini A, DalCorso G. The potential of genetic engineering of plants for the remediation of soils contaminated with heavy metals. Plant, Cell \& Environment. 2018; 41(5): 1201-1232.

[25] Clemens S. Toxic metal accumulation, responses to exposure and mechanisms of tolerance in plants. Biochimie. 2006; 88(11): 1707-1719.

[26] Sarwar N, Malhi SS, Zia MH, Naeem A, Bibi S, Farid G. Role of mineral nutrition in minimizing cadmium accumulation by plant. Journal of the Science of Food and Agriculture. 2010; 90(6): 925-937.

[27] Rehman MZU, Rizwan M, Ali S, Ok YS, Ishaque W, Saifullah, Nawaz MF, Akmal F, Waqar M. Remediation of heavy metal contaminated soils by using Solanum nigrum: a review. Ecotoxicology and Environmental Safety. 2017; 143(1): 236-248.

[28] Gerhardt KE, Gerwing PD, Greenberg BM. Opinion: taking phytoremediation from proven technology to accepted practice. Plant Science. 2017; 256(1): 559-572.

[29] Hasan MM, Uddin MN, Ara-Sharmeen FI, Alharby H, Alzahrani Y, Hakeem KR, Zhang L. Assisting phytoremediation of heavy metals using chemical amendments. Plants. 2019; 8(9): 295.

[30] Liu XM, Wu QT, Banks MK. Effect of simultaneous establishment of Sedum alfridi and Zea mays on heavy metal accumulation in plants. International Journal of Phytoremediation. 2005; 7(1): 43-53.

[31] Lindqvist O, Johansson K, Bringmark L, Timm B, Aastrup M, Andersson A, Hovsenius G, Hakanson L, Iverfeldt A, Meili M. Mercury in the Swedish environment. Water Air Soil Bull. 1991; 55(1-2): xi-261.

[32] Seaward MRD, Richardson DHS. Atmospheric sources of metal pollution and effects on Vegetation. In: Plants Evolutionary Aspects, ed(s) Shaw AJ. Heavy metal Tolerance. Boca Raton, Florida: CRC Press Inc. 1990; 75-92. 
[33] Knox AS, Gamerdinger AP, Adriano DC, Kolka RK, Kaplan DI. Sources and Practices Contributing to soil Contamination. In: Adriano DC, Bollag JM, Frankenberg WT. Jr Sims, RC, eds. Bioremediation of the contaminated soils. Agronomy Series. Wisconson: USA. 1999; 53-87.

[34] Lone MI, He Z, -L, Stoffella PJ, Yang X-E. Phytoremediation of heavy metal polluted soils and water: progresses and perspectives. Journal of Zhejiang University SCIENCE B. 2008; 9(3): 210-220.

[35] Alloway BJ. Heavy Metals in soils. 2nd ed. Berlin: Springer Science \& Business Media. 1995.

[36] Kabata Pendias A. Trace elements in Soils and Plants. 3rd ed. Boca Raton, Florida: CRC Press. 2001.

[37] Nriagu JO, Pacyna JM. Quantitative assessment of worldwide contamination of air water and soils by trace metals. Nature. 1988; 333(6169): 134-139.

[38] Nriagu JO. Arsenic in the environment. Part I. Cycling and characterization. New York: John Wiley and Sons. 1994.

[39] Walsh PR, Duce RA, Finishing JL. Consideration of the enrichment, sources, and flux of arsenic in the troposphere. Journal of Geophysical Research. 1979; 84(C4): 1719-1726.

[40] Blaylock M, Huang J. Phytoextraction of metals. In: Raskin I, Ensley BD. Phytoremediation of Toxic metals: Using plants to clean up the environment. New York: John Wiley \& Sons Inc. 2000; 303.

[41] Djingova R, Kuleff I. Instrumental techniques for trace analysis. In: Vernet JP. Trace elements: Their distribution and effects in the environment. United Kingdom: Elsevier Science Ltd. 2000; 146.

[42] Chibuike GU. Heavy metal polluted soils: Effect on plants and Bioremediation Methods. Applied and Environmental Soil Science. 2014; 6(1): 1-12.

[43] Salt DE, Blaylock M, Kuar PBN, Dushenkov V, Ensley, BD, Chet L, Raskin L. Phytoremediaion: A novel Strategy for the removal of toxic metals from the environment using plants. Biotechnology Journal. 1995; 13(2): 468-474.

[44] Raskin I, Gleba D, Smith R. Using plant seedlings to remove heavy metals from water. Journal of Plant Physiology. 1996; 111(2): 552-552.

[45] Raskin I, Smith RD, Salt DE. Phytoremediation of metals: Using plants to remove pollutants from the environment. Current Opinion in Biotechnology. 1997; 8(2): 221-226.

[46] Sinha RK, Herat S, Tandon PK. Environmental Bioremediation Technologies. Heidelberg, Berlin, Germany: Springer. 2004.

[47] Tangahu BV, Abdullah S, Basri H, Idris M, Anuar N, Mukhlisin M. A Review on Heavy Metals (As, Pb and Hg) Uptake by Plants through Phytoremediation. International Journal of Chemical Engineering. 2011; 4(1): 31.

[48] Prasad MNV, Freitas HMD. Metal hyperaccumulation in plants- Biodiversity prospecting for phytoremediation technology. Electronic Journal of Biotechnology. 2003; 93(1): 285-321.

[49] Burken JG, Schnoor JL. Phytoremediation: plant uptake of atrazine and role of root exudates. Journal of Environmental Engineering. 1996; 122(11): 958-963.

[50] Ginneken LV, Meers E, Guisson R, Ruttens A, Elst K, Tack MG, Vangronsveld J, Diels L, Dejonghe W. Phytoremediation for heavy metal- contaminated soils combined with bioenergy production, Journal of Environmental Engineering and Landscape management. 2007; 15(4): 227-236.

[51] Han YL, Yuan HY, Hung SZ, Guo Z, Xia B, Gu JG. Cadmium tolerance and accumulation by two species of Iris. Ecotoxicology. 2007; 16(8): 557-563.

[52] Caldelas C, Araus JL, Febrero A, Bort J. Accumulation and toxic effects of Chromium and Zinc in Iris pseudacorus L. Acta Physiologiae Plantarum. 2012; 34(3): 1217-1228.

[53] Cassiera PF, Blanke MM, Guerrero GJ. Iron tolerance in Calla lilies (Zantedeschia aethiopica). Gesunde Pflanzen. 2014; 66(2): 63-68.

[54] Trigueros D, Mingorance MD, Olivia RS. Evaluation of the ability of Nerium oleander L. to remediate Pbcontaminated soils. Journal of Geochemical Exploration. 2012; 114(1): 126-133.

[55] Chatterjee S, Singh L, Chattopadhyay B, Datta S, Mukhopadhyay SK. A study on the waste metal remediation using floriculture at East Calcutta Wetlands, a Ramsar site in India. Environmental Monitoring and Assessment. 2012; 184(8): 5139-5150. 
[56] Liu J, Zhou Q, Wang S. Evaluation of chemical enhancement on phytoremediation effect of Cd-contaminated soils with Calendula officinalis L. International Journal of Phytoremediation. 2010; 12(5): 503-515.

[57] Liu J, Zhou Q, Sun T, Ma L, wang S. Growth responses of three ornamental plants to Cd and Cd-Pb stress and their metal accumulation characteristics. Journal of Hazardous Material. 2008; 151(1): 261- 267.

[58] Hao XZ, Zhou DM, Li DD, Jiang P. Growth, Cadmium and Zinc accumulation of ornamental sunflower (Helianthus annus L.) in Contaminated soil with different amendments. Pedosphere. 2012; 22(5): 631-639.

[59] Cassina L, Tassi E, Pedron F, Petruzzelli, G, Ambrosini P, Barbafieri M. Using a plant hormone and a thioligand to improve phytoremediation of $\mathrm{Hg}$-contaminated soil from a petrochemical plant. Journal of Hazardous Materials. 2012; 231-232(1): 36-42.

[60] Wong MH. Ecological restoration of mine degraded soils, with emphasis on metal contaminated soils. Chemosphere. 2003; 50(6): 775-780.

[61] Marques AP, Rangel AO, Castro PM. Remediation of heavy metals contaminated soils: phytoremediation as a potentially promising clean-up technology. Critical Reviews in Environmental Science and Technology. 2009; 39(8): 622-654.

[62] Ginn BR, Szymanowski JS, Fein JB. Metal and proton binding onto the roots of Fescue rubra. Chemical Geology. 2008; 253(3-4): 130-135.

[63] Yan A, Wang Y, Tan SN, Mohd Yusof, Lokmad M, Ghosh S, Chen Z. Phytoremediation: A promising Approach for Revegetation of heavy metal-polluted Land. Frontiers in Plant Sciences. 2020; 11(1): 359.

[64] Vangronsveld J, Herzig R, Weyens N, Boulet J, Adriaensen K, Ruttens A, Thewys T, Vassilev A, Meers E, Nehnevajova E, Lelie DV, Mench M. Phytoremediation of contaminated soils and groundwater: lessons from the field. Environmental Science and Pollution Research. 2009; 16(7): 765-794.

[65] Mench M, Lepp N, Bert V, Schwitzguebel JP, Gawronski SW, Schroder P, Vangronsveld J. Successes and limitations of phytotechnologies at field scale: Outcomes, assessment and outlook from COST action. 859. Journal of Soil and Sediments. 2010; 10(6): 1039-1070.

[66] Rock S, Pivetz B, Mandalinski K, Adams N, Wilson T. Introduction to Phytoremediation: EPA/600/R-99/107 (NTIS PB2000-106690). U. S. Enviromental Protection Agency. 2000.

[67] Alvarenga P, Gonlaves A, Fernandes R, De Varennes A, Vallini G, Duarte E, Queda AC. Organic residues as immobilizing agents in aided phytostabilization:(I) Effects on soil chemical characteristics. Chemosphere. 2009; 74(10): 1292-1300.

[68] Epelde L, Becerril JM, Mijangos I, Garbisu C. Evaluation of the efficiency of a phytostabilization process with biological indiators of soil health. Journal of Environmental Quality. 2009; 38(5): 2041-2049.

[69] Burges A, Alkorta I, Epelde I, Garbisu C. From Phytoremediation of soil contaminants to phytomanagement of ecosystem services in metal contaminated sites. International Journal of Phytoremediation. 2018; 20(4): 384397.

[70] Gohre V, Paszkowski U. Contribution of the arbuscular mycorrhizal symbiosis to heavy metals phytoremediation. Planta. 2006; 223(6): 1115-1122.

[71] Mastretta C, Taghavi S, Lelie, D, Mengoni A, Galardi F, Gonnelli C, Barac C, Boulet J, Weyens N, Vangronsveld J. Endophytic bacteria from seeds of Nicotiana tabacum can reduce Cadmium phytotoxicity. International Journal of Phytoremediation. 2009; 11(3): 251-267.

[72] Ma Y, Prasad M, Rajkumar M, Freitas H. Plant growth promoting rhizobacteria and endophytes accelerate phytoremediation of metalliferous soils. Biotechnology Advances. 2011; 29(2): 248-258.

[73] Salt DE, Blaylock M, Kumar PN, Dushenkov V, Ensley BD, Chet L, Raskin L. Phytoremediation: A novel Strategy for the removal of toxic metals from the environment using plants. Biotechnology Journal. 1995; 13(2): 468-474.

[74] Jacob JM, Karthik C, Saratale RG, Kumar SS, Prabakar D, Kadirvelu K, Pugazhendhi A. Biological approaches to tackle heavy metal pollution: a survey of literature. Journal of Environmental Management. 2018; 217(1): 56-70.

[75] Ali H, Khan E, Sajad MA. Phytoremediation of heavy metals- concepts and applications. Chemosphere. 2013; 91(7): 869-881. 
[76] Sarwar N, Imran M, Shaheen MR, Ishaque W, Kamran MA, Matloob A, Rehmin A, Hussain S. Phytoremediation strategies for soils contaminated with heavy metals: modifications and future perspectives. Chemosphere. 2017; 171(1): 710-721.

[77] Seth CS. A review on mechanisms of plant tolerance and role of transgenic plants in environmental clean-up. The Botanical Review. 2012; 78(1): 32-62.

[78] Robinson BH, Leblanc M, Petit D, Brooks RR, Kirkman JH, Gregg PE. The potential of Thlaspi caerulescens for phytoremediation of contaminated soils. Plant and Soil. 1998; 203(1): 47-56.

[79] Salt DE, Smith RD, Raskin L. Phytoremediation. Annual Review of Plant Physiology and Plant Molecular Biology. 1998; 49(1): 643-668.

[80] Rascio N, Navari-Izzo F. Heavy metal hyperaccumulating plants: how and why they do it? And what makes them so interesting? Plant Science. 2011; 180(2): 169-181.

[81] Van der Ent A, Baker AJ, Reeves RD, Pollard AJ, Schat H. Hyperaccumulators of metal and metalloid trace elements: facts and fiction. Plant and Soil. 2013; 362(1-2): 319-334.

[82] Suman J, Uhlik 0, Viktorova J, Macek T. Phytoextraction of heavy metals: a promising tool for clean-up of polluted environment? Frontiers in Plant Science. 2018; 9(1): 1476.

[83] Reeves RD, Baker AJM. Metal accumulating Plants. In: Raskin I, Ensley BD. Phytoremediation of Toxic Metals. New York, USA. 2000; 193-229.

[84] Kalve S, Sarangi BK, Pandey RA, Chakravarti T. Arsenic and chromium hyperaccumulation by an ecotype of Pteris vittate- prospective for phytoextraction from contaminated water and soil. Current Science Journal. 2011; 100(6): 888-954.

[85] Shah K, Mankad A, Reddy MN. Cadmium accumulation and its effects on growth and biochemical parameters in Taegetes erecta L. Journal of Pharmacognosy and Phytochemistry. 2017; 6(3): 111-115.

[86] Shah K, Mankad A, Reddy MN. Lead accumulation and its effects on growth and biochemical parameters in Taegetes erecta L. International Journal of Life-Sciences Scientific Research. 2017; 3(4): 1142-1147.

[87] Binola D, Pandya D, Mankad A. Effect of lead and cadmium on the growth parameters and protein content of Coleus blumei Benth and heavy metal extraction capacity. International Journal of Science and Research. 2020; 9(10): 426-430.

[88] Pandya J, Mankad A. Effect of Metal Toxicity on Plant Growth and Metabolism of Datura stramonium L. plant. International journal of Research and Analytical Review. 2019; 6(2): 291-300.

[89] Pandya D, Mankad A, Pandya H. Mitigation of Heavy metals from the soil through in-vitro and in-vivo produced plants Impatients balsamina L. International journal of Resarchers in Biosciences, Agriculture and Technology. 2021; 2(9): 226-230.

[90] Pandya D, Mankad A, Pandya H. Biotechnological approach to increase the metal stress tolerance capacity of Impatients balsamina L. Research Journal of Agricultural Sciences. 2020; 11(5): 1110-1114.

[91] Chaney RL, Broadhurst CL, Centofanti T. Phytoremediation of soil trace elements. In: Hooda PS. Trace elements in soil. Chichester: John Wiley \& Sons, Inc. 2010; 311-352.

[92] Lombi E, Zhao FJ, Dunhan SJ, McGrath SP. Phytoremediation of heavy metal-contaminated soils: Natural hyperaccumulation versus chemically enhanced phytoextraction. Journal of Environmental Quality. 2001; 30(6): 19191926.

[93] Przybylowicz JM, Nakonieczny M, Migula P, Augustiniak M, Tarnawaska M, Reimold U, Koeberl C, Przybylowicz Glowacka E. Uptake of Cadmium, lead, nickel and Zinc from soil and water solutions by the nickel hyperaccumulator Berkheya Coddii. Acta Biologica Cracoviensia Series Botanica. 2004; 46(1): 75-85.

[94] Pulford ID, Watson C. Phytoremediation of heavy metal-contaminated land by trees- A review. Environment International. 2003; 29(4): 529-540.

[95] Pilon Smits E. Phytoremediation. Annual Review of Plant Biology. 2005; 56(1): 15-39. 